\title{
STATUS REPORT FOR THE HARPER HOSPITAL SUPERCONDUCTING CYCLOTRON NEUTRON THERAPY FACILITY
}

\author{
R.L. Maughan, M. Yudelev, J. Farr, J.D. Forman, Gershenson Radiation Oncology Center, \\ Karmonos Cancer Center \& Wayne State University, Detroit, MI 48201, USA \\ E.J. Blosser, MedCyc Corporation, E. Lansing, MI 48824, USA \\ T. Horste, TD Engineering, Milford MI USA
}

\section{INTRODUCTION}

During the past three years the number of neutron therapy patients treated at the Gershenson Radiation Oncology Center has remained approximately constant. The facility is operating at maximum load, approximately 9500 fields per year. In the present paper, data for the clinical load and usage of the cyclotron, since it entered routine clinical operation March 1992 are presented, together with data on machine downtime for the period March 1993 - February 2001. Recent and ongoing cyclotron improvement projects are described, including redesign work on the ion source, the beryllium target, the cryogenic and vacuum systems. The major improvement project, however, is the construction of a computer controlled multileaf collimator (MLC) to replace the existing multirod collimator[1] (MRC), which has been in use since patient treatments started in September 1991.

\section{PATIENT LOAD}

A summary of the operating statistics of the neutron therapy facility for its nine years of operation is given in Table 1. Although the downtime in the past two years has increased considerably $(22.5 \%$ and $11 \%$ compared to a norm of approx. 7\%) the number of patients and fields treated has remained approximately constant. Table 2 shows that since 1997 there have been many months in which over 900 fields have been treated, with an average of 23 patients starting treatment in these months. As many as 1269 fields have been treated in a single month. Clearly, the facility has been operating at or close to full capacity for the past several years. In the nine years ending in February 2001 a total of 1499 patients have been treated with neutron radiation therapy at Harper Hospital. Table 3 shows that the majority of these patients $(77.9 \%)$ were treated for adenocarcinoma of the prostate. Head and neck tumors including parotid gland tumors, which are mainly of adenoid cystic histology account for $7.3 \%$ of the cases. Soft tissue and osteo or chondrosarcomas account for $4.34 \%$ and lung tumors contribute $3.3 \%$. These four categories represent the major tumor sites which have been identified in the literature as being suitable for fast neutron therapy[2]. Details of the results of clinical trials performed at the Gershenson Radiation Oncology Center for the treatment of adenocarcinoma can be found in the work of Forman[3].

\section{DOWNTIME}

Detailed records of the cyclotron downtime have been kept since March 1993. The accelerator is considered

Table 1: Summary of operating statistics, March 1991 to February 2001

\begin{tabular}{|c|c|c|c|c|c|c|c|c|}
\hline $\begin{array}{c}\text { Year of } \\
\text { Operation }\end{array}$ & $\begin{array}{c}\text { \# of } \\
\text { Patients }\end{array}$ & $\begin{array}{c}\text { \# of T, } \\
\text { Sessions }\end{array}$ & $\begin{array}{c}\text { \# of } \\
\text { Fields }\end{array}$ & $\begin{array}{c}\text { Fields } \\
\text { per } \mathbf{T}_{\mathbf{x}} \\
\text { Sessions }\end{array}$ & $\begin{array}{c}\mathbf{T}_{\mathbf{x}} \text { Sessions } \\
\text { per Day }\end{array}$ & $\begin{array}{c}\text { Fields } \\
\text { Treated } \\
\text { per Day }\end{array}$ & $\begin{array}{c}\text { \% } \\
\text { Available }\end{array}$ & $\begin{array}{c}\text { \% of Time } \\
\text { Utilized }\end{array}$ \\
\hline $1992-1993$ & 42 & 299 & 711 & 2.38 & 1.18 & 2.80 & N.A. & 13.1 \\
\hline $1993-1994$ & 135 & 1392 & 3910 & 2.81 & 5.54 & 15.3 & 80.8 & 60.4 \\
\hline $1994-1995$ & 120 & 1124 & 3435 & 3.06 & 4.47 & 13.7 & 91.6 & 49.5 \\
\hline $1995-1996$ & 159 & 1563 & 6123 & 3.92 & 6.2 & 22.9 & 92.7 & 68.9 \\
\hline $1996-1997$ & 194 & 1928 & 7244 & 3.76 & 7.78 & 29.0 & 92.7 & 71.5 \\
\hline $1997-1998$ & 223 & 2198 & 9085 & 4.13 & 8.67 & 35.9 & 93.2 & 83.9 \\
\hline $1998-1999$ & 217 & 2059 & 8451 & 4.10 & 8.11 & 33.4 & 93.0 & 79.5 \\
\hline $1999-2000$ & 220 & 2037 & 9570 & 4.68 & 7.91 & 36.98 & 77.5 & 75.5 \\
\hline $2000-2001$ & 189 & 1979 & 9530 & 4.83 & 7.97 & 38.4 & 89.0 & 82.0 \\
\hline
\end{tabular}


Table 2: Statistics for months when $>900$ fields were treated

\begin{tabular}{|c|c|c|c|c|c|}
\hline Year & Month & \# of T $\mathbf{x}$ Sessions & \# of Fields & $\begin{array}{c}\mathbf{T}_{\mathbf{x}} \text { Sessions per } \\
\text { Day }\end{array}$ & Fields per Day \\
\hline \multirow{2}{*}{1997} & June & 219 & 936 & 10.6 & 45.3 \\
& Oct. & 246 & 989 & 10.9 & 44.0 \\
& Dec. & 216 & 964 & 9.8 & 43.8 \\
\hline \multirow{2}{*}{1998} & April & 223 & 905 & 10.1 & 41.1 \\
& Sept. & 227 & 996 & 10.3 & 45.3 \\
& Oct. & 235 & 1015 & 10.7 & 46.1 \\
\hline \multirow{2}{*}{1999} & March & 194 & 927 & 8.4 & 40.3 \\
& April & 215 & 914 & 9.8 & 41.5 \\
& June & 242 & 1020 & 11.0 & 46.4 \\
& Sept. & 197 & 981 & 9.4 & 46.7 \\
& Oct. & 261 & 1267 & 12.1 & 58.9 \\
& Nov. & 251 & 1095 & 12.0 & 52.1 \\
\hline 2000 & Aug. & 199 & 1049 & 10.0 & 52.5 \\
& Sept. & 195 & 994 & 9.8 & 49.7 \\
& Oct. & 227 & 967 & 10.3 & 44. \\
& Nov. & 202 & 1011 & 9.6 & 48.1 \\
\hline 2001 & Jan. & 190 & 993 & 8.6 & 45.1 \\
\hline
\end{tabular}

to be "down" if it is not available for treatment at anytime during the scheduled clinical working day which extends from 7:00am to 5:00pm. Table 4 gives a breakdown of the major causes of downtime for the period from March 1993 to February 2001; the data is categorized into the major cyclotron subsystems.

Four subsystems, the RF generator, the ion source, the magnet and its associated cryogenics and the multirod collimator, account for $67.5 \%$ of the downtime. Operator error remains a significant factor contributing $12.1 \%$ of the downtime. Data for these major sources of downtime are presented in Table 5 for each operating year (March through February) since 1993. The RF system has been the major cause of downtime during three of the eight documented years. Over $80 \%$ of the RF downtime has occurred in two years (1993-1994, 1999-2000); In the first of these years a water leak in the RF cooling inside the beam chamber resulted in a prolonged shut down while water vapor was pumped from the accelerator. In 1999-2000 the RF coupler failed on two separate occasions; new RF parts had to be fabricated and repaired radioactive RF components sent to Los Almos National Laboratory for silver plating. In the same year ion source problems resulting from contamination of the ion source resulted in a prolonged shut down. The situation was further exacerbated on restarting by operator errors resulting in a beryllium target failure and water leakage into beam vacuum. Many of these problems could have been avoided if adequate spare parts had been available. However, manufacture of a spare ion source assembly and spare coupler parts had been delayed by lack of adequate personnel: a direct result of the fiscal problems at the Detroit Medical Center.
Table 3: Patient treatment summary; 3/ $92-2 / 01$

\begin{tabular}{|l|c|c|}
\hline $\begin{array}{c}\text { Anatomical Site/ } \\
\text { Histology }\end{array}$ & $\begin{array}{c}\text { Number of } \\
\text { Patients }\end{array}$ & $\begin{array}{c}\text { Percent } \\
\text { of Total }\end{array}$ \\
\hline Prostate & 1168 & 77.92 \\
\hline Head and Neck & 73 & 4.87 \\
\hline Sarcoma & 65 & 4.34 \\
\hline Lung & 49 & 3.27 \\
\hline Parotid & 37 & 2.47 \\
\hline Pancreas & 18 & 1.20 \\
\hline Gynecologic & 8 & 0.73 \\
\hline Breast & 8 & 0.53 \\
\hline Rectum & 62 & 0.53 \\
\hline $\begin{array}{l}\text { Others (less than } \mathbf{0 . 5 \%} \text { of } \\
\text { Total) }\end{array}$ & $\mathbf{1 4 9 9}$ & $\mathbf{1 0 0 . 0 0}$ \\
\hline TOTAL
\end{tabular}

Table 4: Downtime Summary

\begin{tabular}{|l|c|c|}
\hline \multicolumn{1}{|c|}{ Cause/Problem } & Hours & $\begin{array}{c}\text { \% of } \\
\text { Downtime }\end{array}$ \\
\hline RF Generator & 568.1 & 26.46 \\
\hline Ion Source & 336.8 & 15.69 \\
\hline Magnet/Cryogenics & 278.4 & 12.97 \\
\hline Collimator & 266.7 & 12.42 \\
\hline Operator Error & 259.0 & 12.06 \\
\hline Unspecified & 111.1 & 5.18 \\
\hline Dose Control Console & 71.2 & 3.32 \\
\hline Vacuum & 68.5 & 3.19 \\
\hline Other (each 3\% of total) & 187.0 & 8.71 \\
\hline TOTAL & $\mathbf{2 1 4 6 . 8}$ & $\mathbf{1 0 0 . 0 0}$ \\
\hline
\end{tabular}


Table 5: Annual Downtime Statistics

\begin{tabular}{|l|c|c|c|c|c|}
\hline \multicolumn{1}{|c|}{ Year } & RF System & Ion Source & Mag/Cryogenics & Collimator & Operator Error \\
\hline $\mathbf{1 9 9 3 - 1 9 9 4}$ & $\mathbf{2 1 8 . 6}$ & 15.7 & 47.6 & 13.6 & 56.3 \\
\hline $\mathbf{1 9 9 4 - 1 9 9 5}$ & $\mathbf{6 4 . 2}$ & 7.9 & 35.0 & 18.6 & 8.1 \\
\hline $\mathbf{1 9 9 5 - 1 9 9 6}$ & 11.0 & 26.7 & 13.7 & $\mathbf{3 1 . 8}$ & 9.7 \\
\hline $\mathbf{1 9 9 6 - 1 9 9 7}$ & 4.3 & 10.2 & $\mathbf{6 3 . 4}$ & 20.5 & 10.3 \\
\hline $\mathbf{1 9 9 7 - 1 9 9 8}$ & 6.4 & 37.8 & 11.7 & $\mathbf{6 8 . 5}$ & 2.7 \\
\hline $\mathbf{1 9 9 8 - 1 9 9 9}$ & 11.6 & 28.8 & 11.9 & $\mathbf{3 4 . 8}$ & 31.6 \\
\hline $\mathbf{1 9 9 9 - 2 0 0 0}$ & $\mathbf{2 3 4 . 0}$ & 135.7 & 2.8 & 18.1 & 140.0 \\
\hline $\mathbf{2 0 0 0 - 2 0 0 1}$ & 18.0 & 74.0 & $\mathbf{9 2 . 3}$ & 60.8 & 0.3 \\
\hline TOTAL & $\mathbf{5 6 8 . 1}$ & $\mathbf{3 3 6 . 8}$ & $\mathbf{2 7 8 . 4}$ & $\mathbf{2 6 6 . 7}$ & $\mathbf{2 5 9 . 0}$ \\
\hline
\end{tabular}

\section{CYCLOTRON IMPROVEMENTS}

During the past three years efforts to improve the cyclotron performance and efficiency have focused on the following areas: the ion source, the magnet cryogenic system, the beryllium target, the beam chamber vacuum system and the neutron collimator. The Ion source is a PIG type source and performances was improved by (1) elongating the aperture in the chimney in a direction perpendicular to the median plane of the magnet, (2) using $99.999 \%$ pure deuterium gas rather than $99.9 \%$ purity, (3) redesigning insulators, and (4) improving the cathode water cooling. These changes produced in improved beam output, and improved plasma condition, which resulted in more reliable operation with less source erosion and a subsequent reduction in maintenance and cleaning needs

A new transfer line has been installed between the helium storage dewar and the cyclotron. The helium liquefier (Koch/PSI 1200) has been decontaminated and refurbished; new charcoal filter beds have been installed. These improvements should allow for the development of a continuous flow helium system [4].

The internal beryllium target is positioned in the accelerator chamber at a glancing angle of $20^{\circ}$. A target with a reduced glancing angle of $7^{\circ}$ has been built; this should result in improved cooling which will allow the incident beam current to be increased from its present $15 \mu \mathrm{A}$ maximum.

Two additional 300 1/s turbo pumps have been added to the beam acceleration chamber. These pumps reduced the pump down time after venting the accelerator chamber to atmospheric pressure from 8 hours to 2.5 hours. This improvement should help to reduce downtime.

A MLC has been designed and is presently being constructed, which will reduce the time to irradiate each treatment field and, thus allow for 50\% more patients to receive neutron therapy treatment in Detroit. The device is described in more detail in these proceedings [5].

\section{CONCLUSIONS}

The neutron therapy program at the Gershenson Radiation Oncology Center is the busiest in the world and is operating at full capacity. A computerized MLC is being constructed, which should improve patient throughput by about $50 \%$.

\section{REFERENCES}

[1] R.L. Maughan, G.F. Blosser, E.J. Blosser, M. Yudelev, J.D. Forman, H.G. Blosser, W.E. Powers, "A Multirod Collimator for Neutron Therapy", Int. J. Radiat. Oncol. Biol. Phys., 34, 411, 1996.

[2] G.G. Laramore, "The Use of Neutrons in Cancer Therapy: A Historical Perspective Through the Modern Era", Seminars in Oncology 24, 672, 1997.

[3] J.D. Forman, "Cancer Therapy with the Detroit Superconducting Cyclotron", Ibid.

[4] R.L. Maughan, M. Yudelev, A.T. Porter, J.D. Forman, H.G. Blosser, E.J. Blosser and G.F. Blosser, "Four years of operating experience wit the Harper Hospital Superconducting Cyclotron for Neutron Radiation Therapy", In Cyclotrons and Their Application, ed. J.C. Cornell (World Scientific, London, 1996) pp. 504-507.

[5] J. Farr, R.L. Maughan, J.D. Forman, E.J. Blosser, T.D. Horste, "A Multileaf Collimator for Neutron Radiation Therapy", Ibid. 